\title{
Xestocephalus van Duzee: descrições de seis espécies novas (Hemiptera, Auchenorrhyncha, Cicadellidae, Xestocephalinae) ${ }^{1}$
}

\author{
Adenomar Neves de Carvalho ${ }^{2,3}$ \\ Rodney Ramiro Cavichioli ${ }^{2,4}$
}

\begin{abstract}
Xestocephalus van Duzee: descriptions of six new species (Hemiptera, Auchenorrhyncha, Cicadellidae, Xestocephalinae). Six new species of Xestocephalus Van Duzee, 1892 are described: $X$. crocatus sp. n., X. punctulatus sp. n., $X$. concolor $\mathbf{s p .} \mathbf{n}$., $X$. coloreus sp. n., $X$. tripartitus sp. n. and $X$. stellatus $\mathbf{s p} . \mathbf{n}$., the former two from Rondônia and others from Paraná, Brasil.

KEY WORDS. Hemiptera, Auchenorrhyncha, Cicadellidae, Xestocephalinae, Xestocephalus.
\end{abstract}

VAN DUZEE (1892) descreveu Xestocephalus, sendo que a espécie-tipo, $X$. pulicarius Van Duzee, 1894, foi designada por DisTANT (1908).

CWIKLA (1985) realizou uma reclassificação do gênero para as espécies da América Norte, América Central e Antilhas, com base em uma análise cladística, na qual propôs sete grupos de espécies e deixando cinco espécies em posição incerta com relação aos grupos propostos. Sinonimizou treze espécies, ilustrou a genitália do macho de $X$. irroratus Osborn, 1924 pondo fim à problemática que envolvia sua identificação e descreveu outras seis espécies novas.

CWIKLA \& WOLDA (1986) descreveram X. vittanotus e X. bifasciatus, todas do Panamá.

NiELSON \& KNIGHT (2000) postularam que Xestocephalus praticamente domina a subfamília Xestocephalinae pelo número de espécie e pela sua distribuição cosmopolita.

No presente trabalho, seis novas espécies são descritas: $X$. crocatus $\mathbf{s p .}$ n., $X$. punctulatus sp. n., $X$. concolor sp. n., $X$. coloreus sp. n., $X$. tripartitus sp. n., $X$. stellatus sp. n., provenientes dos estados de Rondônia e Paraná, Brasil.

Todas as figuras apresentadas neste estudo estão na mesma escala $(0,5 \mathrm{~mm})$ e as macrocerdas foram omitidas. As medidas são fornecidas em milimetros.

A série-tipo está depositada na Coleção de Entomologia Pe. Jesus Santiago Moure, Departamento de Zoologia, Universidade Federal do Paraná (DZUP).

1) Contribuição número 1216 do Departamento de Zoologia, Universidade Federal do Paraná.

2) Departamento de Zoologia, Universidade Federal do Paraná. Caixa Postal 19020, 81531-990 Curitiba, Paraná, Brasil.

3) Bolsista da CAPES. E-mail: adenomar@zipmail.com.br

4) Bolsista do CNPq. E-mail: cavich@bio.ufpr.br 


\section{Xestocephalus crocatus sp. $\mathbf{n}$.}

\section{Figs 1-6}

\section{Localidade-tipo. Vilhena, Rondônia, Brasil.}

Holótipo macho. BRAsIL, Rondônia: Vilhena, 11.XI.1986, C. Elias leg. Alótipo fêmea: Rondônia: Vilhena, 17.XII.1986, C. Elias leg..

Diagnose. Cabeça levemente pronunciada, margem anterior levemente arredondada e mais estreita que o pronoto. Edeago com a haste subcilíndrica e com o ápice afilado; par de processos agudos e basais; gonóporo oval, na porção mediana da haste.

Medidas (holótipo/alótipo). Comprimento total: 3,28/3,88; comprimento mediano da coroa: $0,24 / 0,24$; distância interocular: $0,48 / 0,60$; distância transocular: $0,88 / 1,00$; comprimento mediano do pronoto: $0,40 / 0,48$; distância entre os úmeros: 1,00/1,12; comprimento da tégmina: $2,64 / 3,16$; largura da tégmina no ápice do clavo: 0,80/0,92. Holótipo Macho. Cabeça, em vista dorsal, levemente pronunciada, de comprimento $1 / 2$ da distância interocular e $1 / 4$ a $2 / 7$ da transocular; superfície dorsal da coroa finamente pontuada, com duas fóveas entre os olhos, mais ou menos retangulares, sutura coronal não evidente; ocelos evidentes, situados na margem anterior da coroa e eqüidistantes do ápice da coroa e dos olhos; margem anterior da coroa levemente arredondada, sem carena na transição entre a coroa e a face; lóbulos supra-antenais, em vista dorsal, não evidentes, em vista lateral, mais ou menos oblíquos e carenados; fronte mais ou menos plana, oval, finamente pontuada e impressões musculares não evidentes; sutura frontoclipeal completa; clípeo, em vista ventral, mais ou menos retangular com ápice levemente alargado; loros curtos e semicirculares; antena curta. Pronoto, em vista dorsal, mais largo que a cabeça, com rugosidade transversa, de comprimento mediano 2/5 da distância entre os úmeros; margens látero-posteriores e posterior retilíneas; presença de carena notopleural. Escutelo triangular, finamente pontuado, com exceção dos ângulos basais; sutura transescutelar incompleta. Tégminas 3,3 vezes mais longas que a largura no ápice do clavo; três células ante-apicais fechadas, a interna mais proximal que a média e a externa; ápice da célula ante-apical externa tão proximal quanto o ápice do clavo; quatro células apicais, a terceira mais proximal que a segunda e a quarta; venação evidente, sem plexo de veias ou extranumerárias, apêndice reduzido; ápice arredondado.

Pigóforo (Fig. 1), em vista lateral, mais curto que a largura basal; margem posterior irregular, com processo dorso-apical curto e agudo; macrocerdas distribuídas na porção mediana no terço apical e na margem superior. Valva genital, em vista ventral, mais ou menos retangular e convexa. Placa subgenital (Fig. 2), em vista ventral, bipartida, com base de lados paralelos e com constrição mediana; ápice alargado e curvado dorso-lateralmente; macrocerdas distribuídas na porção mediana. Estilos (Fig. 3), em vista dorsal, sinuosos; lóbulo mediano mais ou menos arredondado e voltado anteriormente; base curta e aguda; ápice alargado em forma de "pé" com calcanhar proeminente; margem posterior serrilhada. Conetivo (Fig. 4), em vista dorsal, trífido, com o dente mediano longo e fortemente agudo. Edeago (Fig. 5), em vista lateral, com a haste delgada, subcilíndrica, 

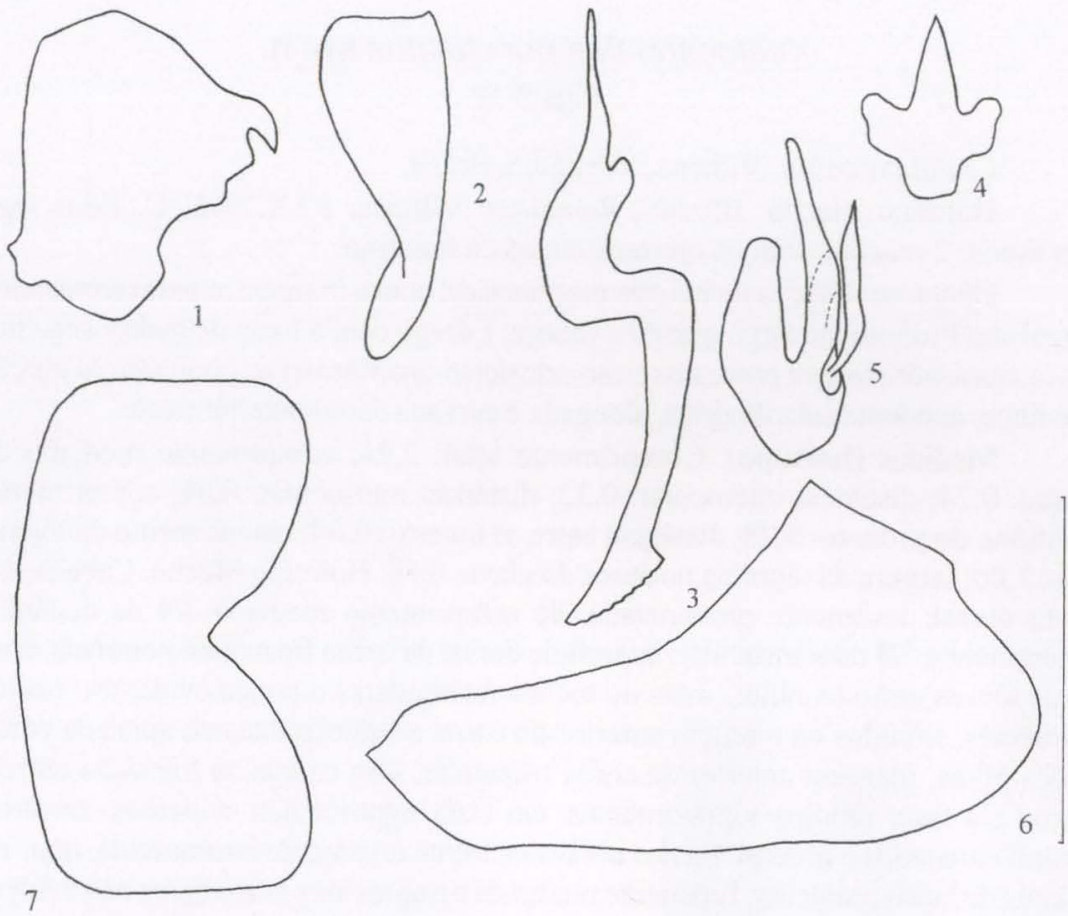

Figs 1-7. Xestocephalus crocatus sp. n. (1) Pigóforo, vista lateral; (2) placa subgenital, vista ventral; (3) estilo, vista dorsal; (4) conetivo, vista ventral; (5) edeago, vista lateral; (6) pigóforo da fêmea, vista lateral; (7) VII esternito, vista ventral.

afilado para o ápice; par de processos basais, longos, agudos e voltados para cima; gonóporo oval na porção mediana; apódema basal alargado medianamente, com o ápice arredondado.

Coloração. Coroa e pronoto alaranjados; margem posterior do pronoto e escutelo marrom-escuros; metade anterior da face marrom-escura, o restante alaranjado. Tégminas marrom-escuras com várias áreas marrom-claras e subhialinas. Tórax e pernas, em vista lateral, marrom-escuros.

Fêmea semelhante ao macho, levemente maior. Pigóforo (Fig. 6), em vista lateral, mais longo do que a largura basal; margem posterior arredondada; macrocerdas distribuídas na porção mediana no terço apical e na margem superior. Esternito VII (Fig. 7), em vista ventral, retangular e convexo; margem posterior com forte reentrância mediana. Câmara genital membranosa.

Comentários. Xestocephalus crocatus $\mathbf{s p}$. n. assemelha-se muito a $X$. desertorum (Berg, 1879) e a X. delongi Cwikla, 1985 na forma do pigóforo, estilos e edeago, porém, pode ser separada destas por apresentar um par de processos basais longos, agudos e voltados para cima; ápice afilado; gonóporo na porção mediana da haste.

Etimologia. O nome da espécie é atribuído em função da cor alaranjada da coroa. 


\section{Xestocephalus punctulatus sp. $\mathbf{n}$.}

\section{Figs $8-12$}

\section{Localidade-tipo. Vilhena, Rondônia, Brasil.}

Holótipo macho. BrasiL, Rondônia: Vilhena, 17.X.1986, C. Elias leg.. Parátipos: 2 machos com os mesmos dados do holótipo.

Diagnose. Cabeça levemente pronunciada, com a margem anterior fortemente angulada. Pronoto tão largo quanto a cabeça. Edeago com a haste delgada e subcilíndrica; ápice afilado sem processos e curvado dorso-anteriormente; gonóporo na porção mediana; apódema subcilíndrica, alongada e curvada dorso-anteriormente.

Medidas (holótipo). Comprimento total: 2,24; comprimento mediano da coroa: 0,24 ; distância interocular: 0,32 ; distância transocular: 0,64 ; comprimento mediano do pronoto: 0,28 ; distância entre os úmeros: 0,64 ; comprimento da tégminas: 2,00; largura da tégmina no ápice do clavo: 0,56. Holótipo Macho. Cabeça, em vista dorsal, levemente pronunciada, de comprimento mediano 3/4 da distância interocular e 3/8 da transocular; superfície dorsal da coroa finamente pontuada, com duas fóveas entre os olhos, mais ou menos retangulares e pouco evidentes; ocelos evidentes, situados na margem anterior da coroa e eqüidistantes do ápice da coroa e dos olhos; margem anterior da coroa triangular, sem carena na transição entre a coroa e a face; lóbulos supra-antenais, em vista superior não evidentes, em vista lateral carenados e mais ou menos oblíquos; fronte levemente intumescida, mais ou menos de lados paralelos, finamente pontuada e impressões musculares não evidentes; sutura fronto-clipeal completa; clípeo, em vista ventral, mais ou menos retangular com o ápice levemente alargado; Lora curtas e semicirculares. Pronoto, em vista dorsal, tão largo quanto a cabeça, com rugosidade transversa, de comprimento mediano 3/7 da distância entre os úmeros; margens látero-posteriores retilíneas; presença de carena notopleural; margem posterior levemente côncava. Escutelo triangular, com superfície lisa; sutura transescutelar incompleta. Tégminas 3,5 vezes mais longas do que a largura no ápice do clavo; três células ante-apicais fechadas, ápice da célula externa tão proximal quanto o ápice do clavo; quatro células apicais, a terceira mais proximal do que a segunda e a quarta; venação pouco evidente, sem plexo de veias ou extranumerárias; apêndice reduzido; ápice arredondado.

Pigóforo (Fig. 8), em vista lateral, mais curto do que a largura basal; margem posterior triangular; em vista posterior, com processo curto, agudo voltado para dentro e para baixo; macrocerdas distribuídas apenas no terço apical. Valva genital, em vista ventral, convexa e mais ou menos retangular. Placa subgenital (Fig. 9), em vista ventral, bipartida, com base de lados paralelos, ápice afilado, arredondado e curvado dorso-lateralmente; macrocerdas distribuídas na porção mediana. Estilos (Fig. 10), em vista dorsal, semilineares; lóbulo mediano curto, triangular e voltado anteriormente; base curta e alargada; ápice agudo com a margem posterior serrilhada, mais ou menos em forma de "pé" com calcanhar não proeminente. Conetivo (Fig. 11), em vista dorsal, curto, trífido, o dente mediano mais longo e largo; base curta e alargada. Edeago (Fig. 12), em vista lateral, com a haste delgada e subcilíndrica; ápice afilado, sem processos e curvado dorso-anteriormente; gonóporo na porção mediana; apódema subcilíndrico, alongado e curvado dorso-anteriormente. 

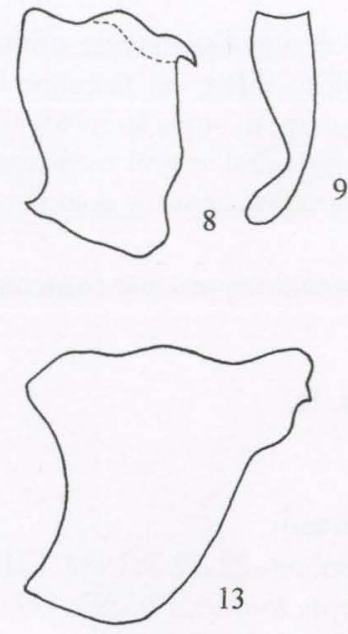

9
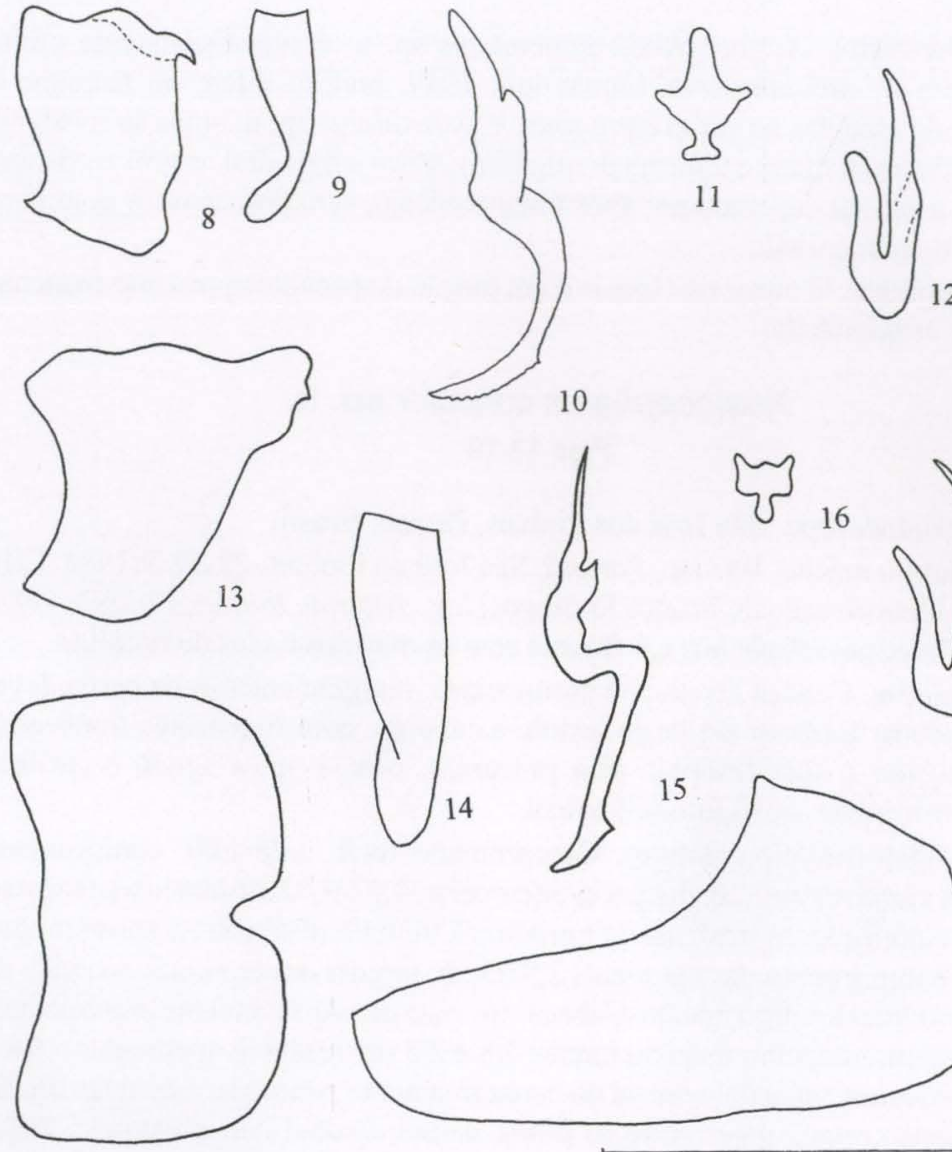

12
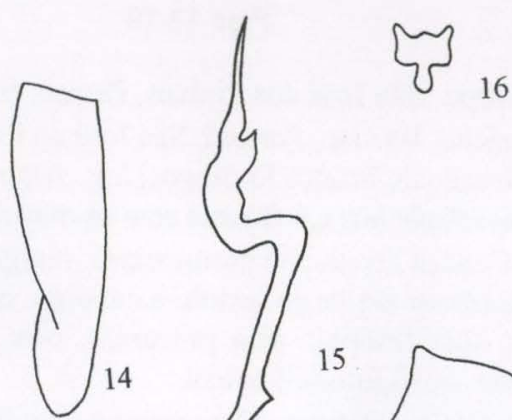

16

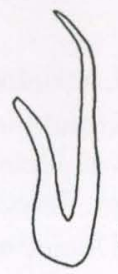

17

19

Figs 8-19. (8-12) Xestocephalus punctulatus sp. n.: (8) pigóforo, vista lateral; (9) placa subgenital, vista ventral; (10) estilo, vista dorsal; (11) conetivo, vista ventral; (12) edeago, vista lateral; (13-19) Xestocephalus concolorsp. n.. (13) pigóforo, vista lateral; (14) placa subgenital, vista ventral; (15) estilo, vista dorsal; (16) conetivo, vista ventral; (17) edeago, vista lateral; (18) pigóforo da fêmea, em vista lateral; (19) VII esternito, em vista ventral.

Coloração. Cabeça marrom-clara com sete máculas esbranquiçadas distribuídas na coroa, sendo três na margem posterior, duas menores próximas aos olhos e duas maiores na porção mediana; mácula circular pequena no ápice da coroa, entre os ocelos; face marrom-clara com uma faixa transversa ligando os olhos, logo abaixo dos ocelos. Pronoto com a mesma coloração, com quatro máculas esbranquiçadas, sendo duas na margem anterior e as restantes na margem posterior; margem lateral com três máculas esbranquiçadas menores dispostas triangularmente. Escutelo marrom-claro. Tégminas marrom-claras com numerosas áreas subhialinas. Tórax e pernas, em vista lateral, marrom-claros esbranquiçados.

Fêmea desconhecida. 
Comentários. Xestocephalus punctulatus sp. n. é superficialmente muito semelhante a $X$. albopunctatus Linnavuori, 1959, porém, difere no tamanho e quantidade de máculas na coroa e pronoto; $X$. punctulatus $\mathbf{s p .} \mathbf{n}$. ainda se relaciona com $X$. desertorum quanto à forma do pigóforo, placa subgenital, estilos e edeago, entretanto, pode ser separada por apresentar o edeago sem processos, o gonóporo mediano e o ápice afilado.

Etimologia. O nome da espécie é em função do pronoto apresentar manchas pequenas e arredondadas.

\section{Xestocephalus concolor sp. $\mathbf{n}$.}

Figs 13-19

\section{Localidade-tipo. São José dos Pinhais, Paraná, Brasil.}

Holótipo macho. BRASIL, Paraná: São José do Pinhais, 22-29.X.1984, CIIF [Centro de Identificação de Insetos Fitófagos] leg. Alótipo. Ibidem, 17-29.X.1984, CIIF leg.. Parátipos: 3 machos e 6 fêmeas com os mesmos dados do holótipo.

Diagnose. Cabeça levemente pronunciada; margem anterior da coroa, levemente angulada. Pronoto tão largo quanto a cabeça e com rugosidade transversa. Edeago delgado e subcilíndrico, sem processos, com o ápice agudo e curvado dorso-anteriormente; gonóporo pré-apical.

Medidas (holótipo/alótipo). Comprimento total: 3,28/4,00; comprimento mediano da coroa: $0,16 / 0,20$; distância interocular: 0,42/0,52; distância transocular: 0,90/1,04; comprimento mediano do pronoto: $0,36 / 0,40$; distância entre os úmeros: $0,96 / 1,12$; comprimento das tégminas: $2,92 / 3,36$; largura das tégminas no ápice do clavo: $0,80 / 0,96$. Holótipo macho. Cabeça, em vista dorsal, levemente pronunciada, de comprimento mediano mais ou menos $3 / 8$ a $2 / 5$ da distância interocular e 1/6 a $1 / 5$ da transocular; superfície dorsal da coroa finamente pontuada, com duas fóveas mais ou menos retangulares entre os olhos; sutura coronal não evidentes; ocelos evidentes, situados na margem anterior da coroa e equidistantes do ápice da coroa e dos olhos; margem anterior da coroa levemente angulada, sem carena na transição entre a coroa e a face; lóbulos supra-antenais, em vista dorsal, não evidentes, em vista lateral, oblíquos e carenados; fronte mais ou menos plana e oval, finamente pontuada e impressões musculares não evidentes; sutura fronto-clipeal completa; clípeo, em vista ventral, retangular com o ápice alargado; lora semicirculares, não atingindo o ápice do clípeo; sutura fronto-genal estendendo-se próximo do ocelo; antenas curtas. Pronoto, em vista dorsal, com rugosidade transversa, levemente mais largo do que a cabeça, de comprimento mediano $3 / 8$ da distância entre os úmeros; presença de carena notopleural; margens látero-posteriores retilíneas; margem posterior levemente côncava. Escutelo triangular, finamente pontuado; sutura transescutelar côncava e incompleta. Tégminas 3,6 vezes mais longas do que a largura no ápice do clavo; três células ante-apicais fechadas e mais basais do que o ápice do clavo; a célula ante-apical externa é extremamente pequena e mais ou menos triangular, situada na base da célula média; quatro células apicais, a terceira mais proximal do que a segunda e a quarta; venação pouco evidente, sem plexo de veias ou extranumerárias; apêndice reduzido; ápice arredondado. 
Pigóforo (Fig. 13), em vista lateral, tão longo quanto a largura basal; margem posterior afilada; margem ventro-apical irregular com processo curto e agudo; macrocerdas distribuídas no terço apical e margem superior. Valva genital, em vista ventral, mais ou menos retangular e convexa. Placa subgenital (Fig. 14), em vista ventral, bipartida, inteira, com ápice alargado e curvado dorso-lateralmente; macrocerdas distribuídas linearmente na porção mediana; ápice com tufo de macrocerdas longas e menos esclerotinizadas. Estilos (Fig. 15), em vista dorsal, alongados e fortemente sinuosos; lóbulo mediano mais ou menos triangular; base fortemente aguda; ápice alargado em forma de "pé" com calcanhar pouco pronunciado. Conetivo (Fig. 16), em vista ventral, em "T", com projeção alongada e aguda na confluência dos braços. Edeago (Fig. 17), em vista lateral, delgado, subcilíndrico, sem processos, com o ápice agudo e curvado dorso-anteriormente; gonóporo pré-apical; apódema delgado, subcilíndrico e curvado dorso-anteriormente.

Coloração. Corpo inteiramente marrom-claro; olhos pretos; tégminas marrom-claras e subhialinas, com máculas marrom-escuras na porção mediana; ápice marrom-escuro.

Fêmea semelhante ao macho, porém, maior. Pigóforo (Fig. 18), em vista lateral, mais longo do que a largura mediana; margem posterior levemente angulada; macrocerdas distribuídas na porção mediana, terço apical e margem superior. Sétimo esternito (Fig. 19), em vista ventral, mais ou menos retangular e convexo; margem posterior côncava. Câmara genital membranosa.

Comentários. Xestocephalus concolor sp. $\mathbf{n}$. assemelha-se a $X$. variabilis DeLong, 1982 e com X. punctulatus sp. n. quanto à forma do edeago. Porém, distingue-se da primeira por apresentar a extremidade apical da haste edeagal curvada dorso-anteriormente; da segunda, por apresentar o gonóporo pré-apical e por apresentar um processo triangular curto na margem ventro-apical do pigóforo.

Etimologia: O nome da espécie é atribuído em função da coloração marromclara uniforme.

\section{Xestocephalus coloreus sp. $\mathbf{n}$.}

Figs 20-24

Localidade-tipo. São José dos Pinhais, Paraná, Brasil.

Holótipo macho. BRAsIL, Paraná: São José do Pinhais, 26.X.1984, CIIF leg..

Diagnose. Cabeça levemente pronunciada; margem anterior levemente arredondada. Pronoto mais largo que a cabeça, com rugosidade transversa. Edeago curto, agudo, sem processos e curvado dorsalmente; apódema curvado para trás e mais ou menos subigual à haste edeagal; três pares de processos basais, agudos e laminares;

Medidas (holótipo). Comprimento total: 3,36; comprimento mediano da coroa: 0,20; distância interocular: 0,56 ; distância transocular: 0,96 ; comprimento mediano do pronoto: 0,44 ; distância entre os úmeros: 1,08 ; comprimento das tégmina: 2,92 ; largura da tégmina no ápice do clavo: 0,88 . Holótipo macho. Cabeça, em vista dorsal, levemente proeminente, de comprimento mediano mais ou menos $1 / 3$ a $3 / 8$ da distância interocular e $1 / 5$ a $2 / 9$ da transocular; superfície dorsal da coroa finamente pontuada, 


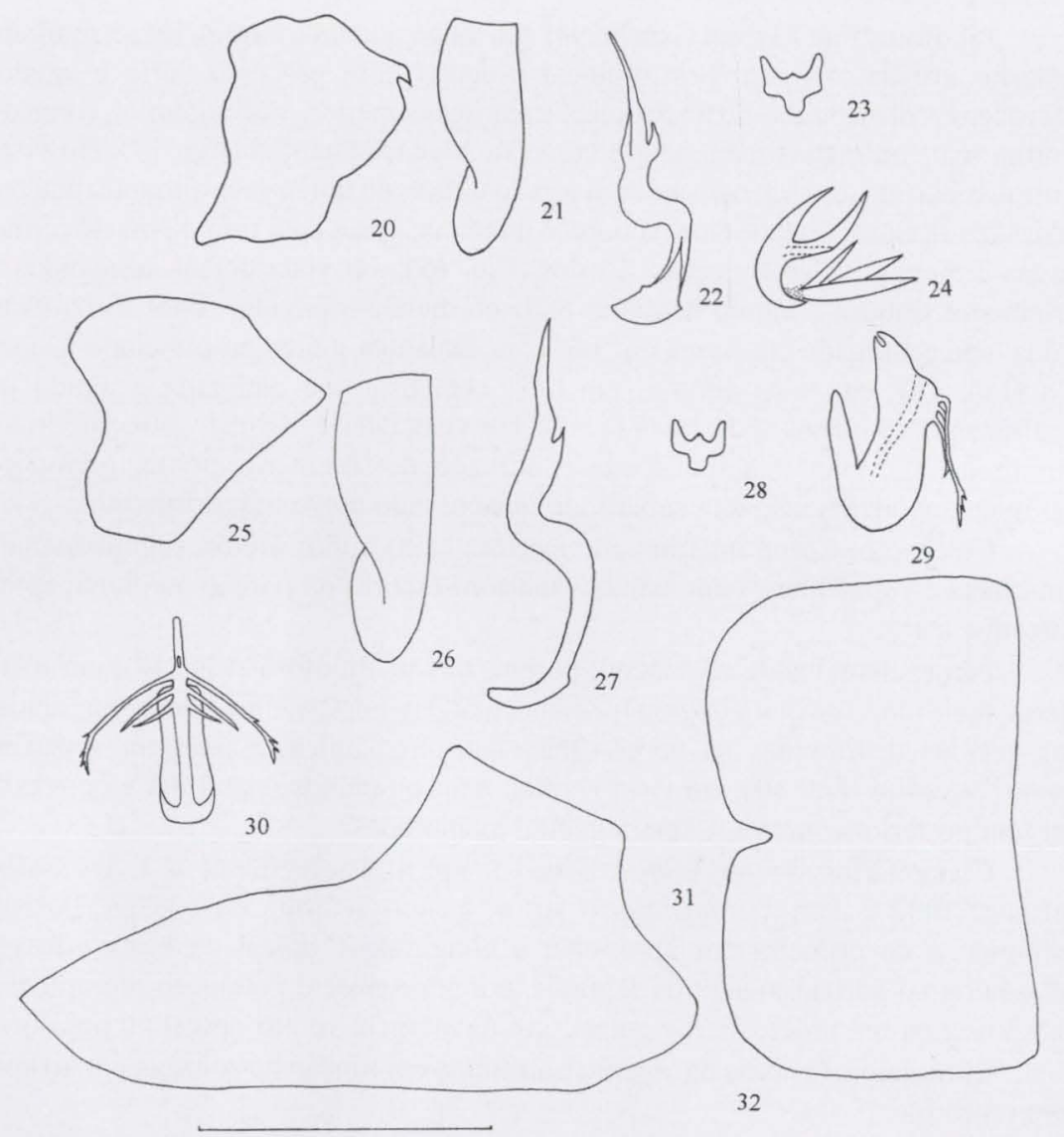

Figs 20-32. (20-24) Xestocephalus coloreus sp. n.: (20) pigóforo, vista lateral; (21) placa subgenital, vista ventral; (22) estilo, vista dorsal; (23) conetivo, vista ventral; (24) edeago, vista lateral; (25-32) Xestocephalus tripartitus sp. n.: (25) pigóforo, vista lateral; (26) placa subgenital, vista ventral; (27) estilo, vista dorsal; (28) conectivo, vista ventral; (29) edeago, vista lateral; (30) edeago, vista posterior; (31) pigóforo da fêmea, vista lateral; (32) VII esternito, vista ventral.

com duas fóveas mais ou menos retangulares entre os olhos; sutura coronal não evidentes; ocelos evidentes, situados na margem anterior da coroa e equidistantes do ápice da coroa e dos olhos; margem anterior da coroa levemente arredondada, sem carena an transição entre a coroa e a face; lóbulos supra-antenais, em vista dorsal, não evidentes, em vista lateral, oblíquos e carenados; fronte mais ou menos plana e oval, finamente pontuada e impressões musculares não evidentes; sutura fronto-clipeal completa; clípeo, em vista ventral, retangular com o ápice alargado; lora semicirculares, não atingindo o ápice do clípeo; sutura fronto-genal estendendo-se próximo do ocelo; antena curta. Pronoto, em vista dorsal, mais largo do que a cabeça, de compri- 
mento mediano mais ou menos $2 / 5$ da distância entre os úmeros, com rugosidade transversa; presença de carena notopleural; margens látero-posteriores retilíneas; margem posterior côncava. Escutelo triangular, finamente pontuado; sutura transescutelar côncava e incompleta. Tégminas 3,3 vezes mais longas do que a largura no ápice do clavo; três células ante-apicais fechadas, mais basais do que o ápice do clavo; ápice da célula ante-apical externa, tão proximal quanto o ápice do clavo; quatro células apicais, a terceira, mais proximal do que a segunda e a quarta; venação pouco evidente, sem plexo de veias ou extranumerárias; apêndice reduzido; ápice arredondado.

Pigóforo (Fig. 20), em vista lateral, mais curto do que a largura basal; margem posterior irregular com processo dorso-apical curto, agudo e curvado para dentro; macrocerdas distribuídas no terço apical e margem superior. Valva genital, em vista ventral, mais ou menos retangular e convexa. Placa subgenital (Fig. 21), em vista ventral, bipartida, inteira, com base de lados paralelos com ápice levemente alargado e curvado dorso-lateralmente; macrocerdas distribuídas na porção mediana. Estilos (Fig. 22), em vista dorsal, subcilíndricos e sinuosos; lóbulo mediano proeminente e agudo; base fortemente aguda; ápice lamelar, alargado com a margem posterior semilinear com uma leve semelhança a de um "pé", cujo calcanhar apresenta-se pouco proeminente. Conetivo (Fig. 23), em vista ventral, em "Y", com projeção alongada e aguda na confluência dos braços. Edeago (Fig. 24), em vista lateral, curto, cilíndrico, fortemente agudo, sem processos e curvado dorsalmente; gonóporo basal; apódema subcilíndrico e curvado para trás, mais ou menos subigual à haste edeagal; base fortemente aguda e voltada para trás; três pares de processos basais, longos, laminares e agudos.

Coloração. Corpo preto, inteiramente maculado de amarelo-escuro e branco; face marrom-escura.

Fêmea desconhecida.

Comentários. Xestocephalus coloreus sp. $\mathbf{n}$. pode ser confundida com $X$. fulvus DeLong, Wolda \& Estribi, 1983 quanto ao padrão de coloração, principalmente o da coroa, porém, pode ser reconhecida por apresentar o edeago com três pares de processos laminares basais.

Etimologia. O nome da espécie é atribuído em função das suas diferentes cores.

\section{Xestocephalus tripartitus sp. $\mathbf{n}$.}

\section{Figs 25-32}

Localidade-tipo. São José dos Pinhais, Paraná, Brasil.

Holótipo macho. BRASIL, Paraná: São José do Pinhais, 16-26.X.1984, CIIF leg. Alótipo com os mesmos dados do holótipo. Parátipos: 2 machos e 2 fêmeas, com os mesmos dados do holótipo.

Diagnose. Cabeça levemente pronunciada; margem anterior angulada. Pronoto com rugosidade transversa e mais largo que a cabeça. Edeago com a haste muito larga, com três pares de processos pré-apicais, o par mais apical apresenta-se alongado e curvado para baixo, carregando três processos espiniformes curtos na margem dorso-apical; gonóporo pré-apical. 
Medidas (holótipo/alótipo). Comprimento total: 3,96/5,36; comprimento mediano da coroa: $0,24 / 0,32$; distância interocular: $0,44 / 0,60$; distância transocular: $0,96 / 1,08$; comprimento mediano do pronoto: $0,48 / 0,60$; distância entre os úmeros: 1,08/1,32; comprimento das tégmina: 3,84/4,76; largura da tégmina no ápice do clavo: 1,08/1,36. Holótipo macho. Cabeça, em vista dorsal, levemente pronunciada, de comprimento mediano mais ou menos $1 / 2$ a $5 / 9$ da distância interocular e 1/4 da transocular; superfície da coroa finamente pontuada, com duas fóveas mais ou menos retangulares entre os olhos; sutura coronal, não evidente; ocelos evidentes, situados na margem anterior da coroa e equidistantes do ápice da coroa e dos olhos; margem anterior da coroa angulada, sem carena na transição entre a coroa e a face; lóbulos supra-antenais, em vista dorsal, não evidentes, em vista lateral, oblíquos e carenados; fronte mais ou menos plana e oval, finamente pontuada e impressões musculares não evidentes; sutura frontoclipeal completa; clípeo, em vista ventral, retangular com o ápice alargado; lora semicirculares, não atingindo o ápice do clípeo; sutura fronto-genal estendendose próximo do ocelo; antenas curtas. Pronoto, em vista dorsal, mais largo do que a cabeça, de comprimento mediano $4 / 9$ da distância entre os úmeros, com rugosidade transversa; presença de carena notopleural; margens látero-posteriores retilíneas; margem posterior levemente côncava. Escutelo triangular, finamente pontuado; sutura transescutelar côncava e incompleta. Tégminas 3,5 vezes mais longas do que a largura no ápice do clavo; três células ante-apicais fechadas, mais basais do que o ápice do clavo; quatro células apicais, a terceira mais proximal que a segunda e quarta; venação pouco evidente, sem plexo de veias ou extranumerárias; apêndice reduzido; ápice arredondado.

Pigóforo (Fig. 25), em vista lateral, tão longo quanto a largura basal; margem posterior triangular sem processos; macrocerdas distribuídas no terço apical e margem superior. Valva genital, em vista ventral, mais ou menos retangular e convexa. Placa subgenital (Fig. 26), em vista ventral, bipartida, inteira, com ápice alargado e curvado dorso-lateralmente; macrocerdas distribuídas na porção mediana. Estilos (Fig. 27), em vista dorsal, subcilíndricos e sinuosos; lóbulo mediano proeminente e agudo; base aguda; ápice afilado e curvado para fora, com pequena elevação na margem apical interna. Conetivo (Fig. 28), em vista ventral, em "Y". Edeago (Fig. 29), em vista lateral, com a haste curta, muito larga e com três pares de processos pré-apicais; apódema curto e delgado; em vista posterior (Fig. 30), o par de processos mais apical alongado e curvado para baixo, carregando três processos espiniformes curtos na margem dorso-apical; ápice afilado com reentrância apical; gonóporo pré-apical.

Coloração. Corpo inteiramente amarelo-claro com máculas e faixas brancas irregulares. Tégminas amarelo-claras com veias brancas; presença de três máculas marrom-escuras no clavo e três na área costal.

Fêmea semelhante ao macho, porém, maior. Pigóforo (Fig. 31), em vista lateral, mais longo do que a largura mediana; margem posterior levemente angulada; macrocerdas distribuídas na porção mediana e terço apical. Sétimo esternito (Fig. 32), em vista ventral, retangular, convexo e com reentrância na margem posterior. Câmara genital membranosa. 
Comentários. Xestocephalus tripartitus sp. n. é superficialmente semelhante à $X$. luridus Linnavuori, 1959 que pode apresentar a coroa com o mesmo padrão de coloração, porém, pode ser diferenciada por apresentar a haste do edeago muito alargada e três pares de processos pré-apicais curvados para baixo.

Etimologia. O nome da espécie é atribuído em função da presença de três processos no edeago.

\section{Xestocephalus stellatus sp. $\mathbf{n}$.}

Figs 33-41

\section{Localidade-tipo. Morretes, Paraná, Brasil.}

Holótipo, BrasiL, Paraná: Morretes, 22-29.X.1984, CIIF leg.. Alótipo: Paraná: São José dos Pinhais, 12-19.XI.1984, CIIF leg.. Parátipos: 2 machos e 8 fêmeas com os mesmos dados do holótipo.

Diagnose. Cabeça levemente pronunciada; margem anterior da coroa levemente arredondada. Pronoto com rugosidade transversa, e levemente mais largo que a cabeça. Edeago delgado, subcilíndrico e com sinuosidade basal; o ápice projetado para baixo, contendo no ápice da projeção um par de processos ramificados, assimétricos e voltados para cima; processo apical simples e delgado voltado dorsalmente; gonóporo apical; apódema delgado, subcilíndrico, voltado para cima e alcançando mais ou menos $2 / 3$ do comprimento mediano da haste edeagal.

Medidas (holótipo/alótipo). Comprimento total: 2,36/3,00; comprimento mediano da coroa: $0,20 / 0,28$; distância interocular: $0,36 / 0,48$; distância transocular: 0,72/0,84; comprimento mediano do pronoto: $0,28 / 0,36$; distância entre os úmeros: 0,74/0,92; comprimento das tégminas: 2,28/2,52; largura das tégminas no ápice do clavo: $0,68 / 0,72$. Holótipo macho. Cabeça, em vista dorsal, levemente pronunciada, de comprimento mediano 5/9 da distância interocular e mais ou menos $1 / 4$ a 2/7 da transocular; superfície dorsal da coroa finamente pontuada, com duas fóveas mais ou menos retangulares entre os olhos; sutura coronal não evidente; ocelos evidentes, situados na margem anterior da coroa e equidistantes do ápice da coroa e dos olhos; margem anterior da coroa levemente arredondada, sem carena na transição entre a coroa e a face; lóbulos supra-antenais, em vista dorsal, não evidentes, em vista lateral, oblíquos e carenados; fronte mais ou menos plana e oval, finamente pontuada e impressões musculares não evidentes; sutura fronto-clipeal completa, clípeo, em vista ventral, retangular com o ápice levemente alargado; Lora semicirculares, não atingindo o ápice do clípeo; sutura fronto-genal estendendo-se próximo do ocelo; antena curta. Pronoto, em vista dorsal, levemente mais largo do que a cabeça, de comprimento mediano mais ou menos $3 / 8$ a $2 / 5$ da distância entre os úmeros, com rugosidade transversa; presença de carena notopleural; margens látero-posteriores retilíneas; margem posterior levemente côncava. Escutelo triangular, finamente pontuado; sutura transescutelar côncava e incompleta. Tégminas 3,3 vezes mais longas do que a largura no ápice do clavo; três células ante-apicais fechadas, mais basais do que o ápice do clavo; quatro células apicais, a terceira mais proximal do que a segunda e a quarta; venação pouco evidente, sem plexo de veias ou extranumerárias; apêndice reduzido; ápice arredondado. 


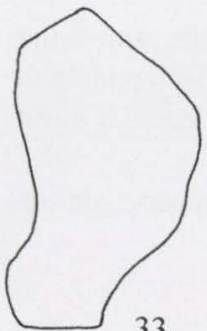

33

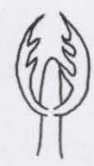

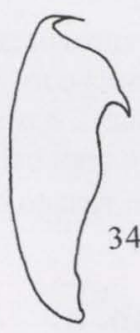

35
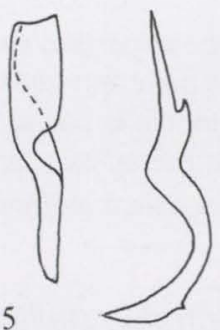

\{\}

37
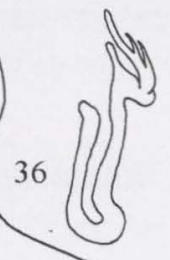

38

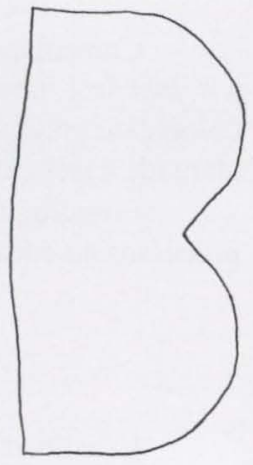

41

40

Figs 33-41. Xestocephalus stellatus sp. n.. (33) Pigóforo, vista lateral; (34) pigóforo, vista posterior; (35) placa subgenital, vista ventral; (36) estilo, vista dorsal; (37) conectivo, vista ventral; (38) edeago, vista lateral; (39)ápice do edeago, vista posterior; (40) pigóforo da fêmea, vista lateral; (41) VII esternito, vista ventral.

Pigóforo (Fig. 33), em vista lateral, mais curto que a largura basal; margem posterior levemente angulada, em vista posterior (Fig. 34), processo dorso apical curto, agudo e curvado para dentro e para baixo; macrocerdas distribuídas na margem posterior e margem superior. Valva genital, em vista ventral, mais ou menos retangular e convexa. Placa subgenital (Fig. 35), em vista ventral, bipartida, inteira, base com lados paralelos e com uma reentrância na margem interna. Estilos (Fig. 36), em vista dorsal, subcilíndricos e sinuosos; lóbulo mediano proeminente e agudo; base afilada; ápice delgado, fortemente agudo e curvado para fora; dente curto e agudo na margem apical interna. Conetivo (Fig. 37), em vista ventral, trífido com dente mediano fortemente agudo. Edeago (Fig. 38), em vista lateral, delgado, subcilíndrico e com sinuosidade basal; $o$ ápice projetado para baixo, com um par de processos ramificados, assimétricos e voltados para cima; processo apical simples e delgado voltado dorsalmente; em vista posterior (Fig. 39), os processos com cinco projeções espiniformes na margem interna; gonóporo apical; apódema delgado, subcilíndrico, voltado para cima e alcançando mais ou menos $2 / 3$ do comprimento mediano da haste do edeago.

Coloração. Coroa marrom-escura com duas máculas brancas na margem dos olhos e, quatro máculas de mesma cor na porção mediana; mácula mais ou menos circular entre os ocelos; pronoto marrom-escuros com dez máculas brancas e circulares. Tégminas marrom-escuras com numerosas máculas brancas e áreas subhialinas.

Fêmea semelhante ao macho, levemente maior. Pigóforo (Fig. 40), em vista lateral, tão longo quanto a largura mediana; margem posterior triangular; macrocer- 
das distribuídas na porção mediana, terço apical e margem superior. Sétimo esternito (Fig. 41), em vista ventral, mais ou menos retangular e convexo; margem posterior com reentrância mediana. Câmara genital membranosa.

Comentários. Xestocephalus stellatus sp. n. pode ser confundida $\operatorname{com} X$. gutattus sp. n. por apresentar o padrão de coloração da coroa e pronoto muito semelhante, porém, esta espécie pode ser reconhecida por apresentar o edeago subcilíndrico, delgado, com um par processos apicais ramificados e voltados para cima. brancas.

Etimologia. O nome da espécie é atribuído em função as várias máculas AGRADECIMENTO. À CAPES pelo apoio financeiro.

\section{REFERÊNCIAS BIBLIOGRÁFICAS}

CWIKLA, P.S. 1985. Classification of the genus Xestocephalus (Homoptera: Cicadellidae) for North and Central America including the West Indies. Brenesia 24: 175-275.

CWIKLA, P.S. \& H. WoldA. 1986. Seasonality and two new species or Panamanian Xestocephalus (Homoptera: Cicadellidae). Proc. Entomol. Soc. Wash. 88 (2): 344-350.

Distant, W.L. 1908. The Rhynchota-Homoptera, p. 348. In: C.T. Bingham (Ed.). The faune of British India including Ceylon and Burma. London, , Vol. 4, 501p.

Nielson, M.W. \& W. KNight. 2000. Distributional patterns and possible origin or leafhoppers (Homoptera, Cicadellidae). Revta bras. Zool. 17 (1): 81-156.

VAN DUZZE, E.P. 1892. A synoptical arrangement of the genera of the North American Jassidae, with descriptions of some species. Trans. Soc. Amer. Entomol. 19: 295-307.

Recebido em 06.VII.2000; aceito em 23.VIII.2001. 